\title{
Acadian and Alleghenian remagnetization of the Jim Pond Formation, central western Maine, northern Appalachians
}

\author{
Art D. Lombard, Ben A. van der Pluijm ${ }^{1}$ and Rob Van der Voo ${ }^{1}$ \\ University of Michigan, Department of Geological Sciences, Ann Arbor, Mich. 48109-1063, USA
}

(Received January 3; 1990; accepted May 2, 1990)

\begin{abstract}
Lombard, A.D., van der Pluijm, B.A. and Van der Voo, R., 1991. Acadian and Alleghenian remagnetization of the Jim Pond Formation, central western Maine, northern Appalachians. Tectonophysics, 186: 279-291.

Samples were collected from ten sites of the Late Cambrian-Early Ordovician Jim Pond Formation for paleomagnetic study. Stepwise thermal demagnetization reveals three separable components of magnetization. Component $I$ is typically removed by $350^{\circ} \mathrm{C}$; it is subparallel to the present day field $\left(354^{\circ} /+76^{\circ}\right.$ vs. $\left.342^{\circ} /+72^{\circ}\right)$ at the site location $\left(45.3^{\circ} \mathrm{N}\right.$, $289.4^{\circ} \mathrm{E}$ ) and is considered to be a recent partial overprint. Component II, without tilt-correction, is a south-southeasterly and shallow direction (mean: $165^{\circ} / 0^{\circ}, k=31.4, a_{95}=8.6^{\circ}$ ) that is removed over an intermediate temperature range $\left(350-600^{\circ} \mathrm{C}\right.$ ). Component III, without tilt-correction, is a northeasterly and shallow, upward direction (mean: $10^{\circ} /-24^{\circ}, k=21.5$, $\left.a_{95}=7.3^{\circ}\right)$ and is removed over the highest temperature range $\left(480^{\circ}\right.$ to $690^{\circ} \mathrm{C}$ ). Though not statistically significant, for Components II and III the precision parameter, $k$, decreases and the $\alpha_{95}$ increases when tilt-correction is applied, suggesting that both are post-folding magnetizations.

Component II, without tilt correction, has a corresponding palcomagnetic polc locatcd at $43^{\circ} \mathrm{N}, 130^{\circ} \mathrm{E}\left(\mathrm{d} p, \mathrm{~d} m-4.3^{\circ}\right.$, $8.6^{\circ}$ ), which falls near the Late Carboniferous segment of the Laurentian Apparent Polar Wander Path (APWP). Component III, without tilt correction, has a corresponding pole located at $32^{\circ} \mathrm{N}, 98^{\circ} \mathrm{E}\left(\mathrm{d} p, \mathrm{~d} m=4.7^{\circ}, 7.8^{\circ}\right)$, which falls near the Lower-Middle Devonian segment of the APWP. We conclude that the Jim Pond Formation has undergone two Paleozoic remagnetization events, one in the Early to Middle Devonian and a second one in the Late Paleozoic. The ages of these remagnetizations coincide with the timing of major orogenic activity in the area, i.e. the Acadian and Alleghenian, respectively. The remagnetization event associated with the Acadian pulse can be recognized in other paleomagnetic investigations in the northern Appalachians.
\end{abstract}

\section{Introduction}

In central western Maine, several intriguing Appalachian units are exposed. The oldest known ophiolite of the northern Appalachians, the Late Cambrian-Farly Ordovician Jim Pond-Boil Mountain Ophiolitic Complex (Boudette, 1982) is located at the southern margin of the Precambrian Chain Lakes Massif (1.6 Ga; Naylor et al., 1973). A geologic map of the area is shown in Fig. 1. The Chain Lakes Massif is an amphibolite-grade exposure of unknown tectonic affinity, which strad-

\footnotetext{
$\overline{1}$ Corresponding authors.
}

dles the U.S.-Canadian border in the vicinity of the Maine-New Hampshire boundary. Osberg (1978) referred to the massif as basement "B", as opposed to Grenvillian basement (basement " $A$ ") to the northwest and younger basement (basement "C") to the southeast. Our mapping shows that the Chain Lakes massif is in tectonic contact with the base of the $520 \pm 12 \mathrm{Ma}$ Boil Mountain Complex (Eisenberg, 1982, p. 43), which is composed of a suite of serpentinite, pyroxenite, gabbro, tonalite, epidiorite, and other compositionallylayered ultramafics. The Boil Mountain Complex is conformably overlain by bimodal volcanics and volcaniclastic sediments of the Jim Pond Formation (500 $\pm 10 \mathrm{Ma}$; Aleinikoff et al., 1985). Major and trace element geochemistry of mafic volcanics 


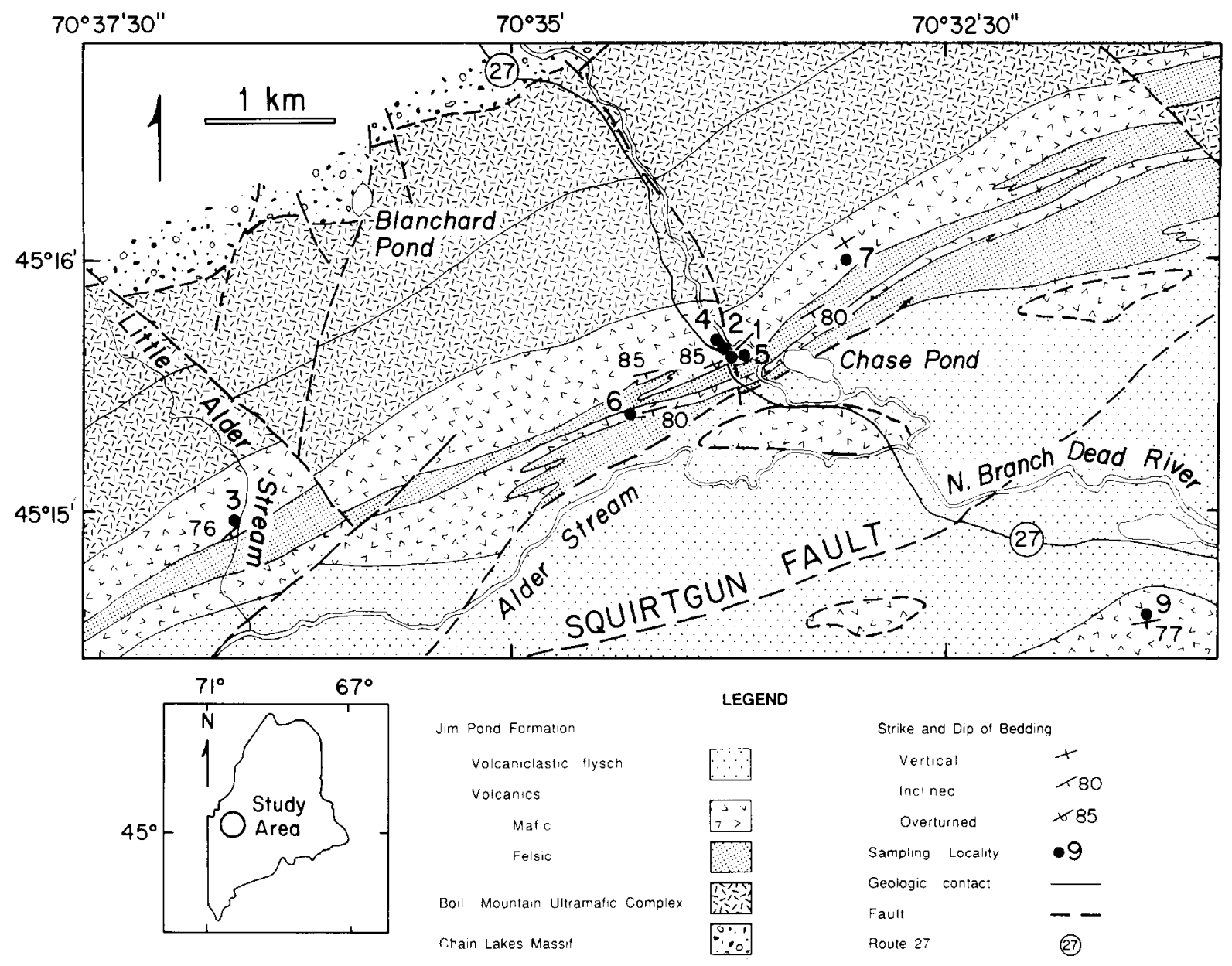

Fig. 1. Generalized geologic map (after Boudette, 1978). Inset shows location of study area; filled black circles are paleomagnetic sampling sites. Two paleomagnetic sites are located to the northeast of the map area; their results were spurious and are not included.

of the Jim Pond Formation indicates that they are of island arc affinity (Eisenberg, 1982; Coish and Rogers, 1987; Lombard et al., 1990). The Jim Pond Formation-Boil Mountain "ophiolite" is not easily correlated with other ophiolites of the northern Appalachians (e.g., Zen, 1983 vs. Coish and Rogers, 1987). Recent geochemical and geophysical data indicate that the Chain Lakes Massif and the Boil Mountain Ophiolite Complex are underlain by Grenvillian basement (Ayuso, 1986; Spencer et al., 1989) following the earlier suggestion of Zen (1983) and Ando et al. (1983).

Boudette (1982) concluded that the Jim Pond Formation was deformed at the time of obduction and again during the Early to Middle Devonian Acadian orogeny. The timing of obduction of the Boil Mountain ophiolite is constrained by stratigraphic relationships. Siluro-Devonian rocks un- conformably overly not only the uppermost sedimentary units of the Jim Pond Formation (as shown in Fig. 2, after Boudette and Boone, 1976),

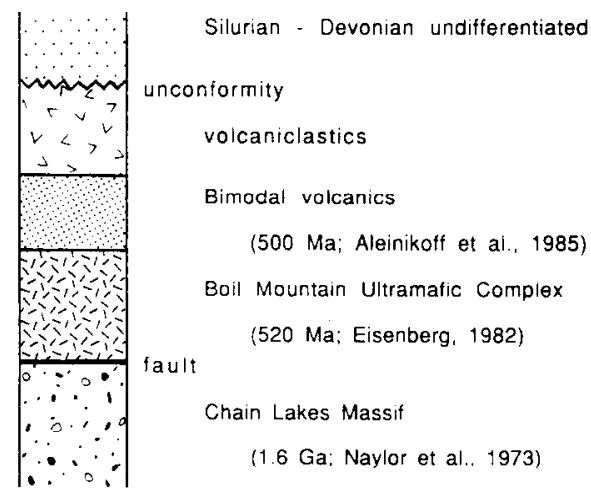

Fig. 2. Stratigraphic column showing relationships between the important geologic elements: (1) the Chain Lakes Massif and (2) the Jim Pond-Boil Mountain Ophiolite and (3) the SiluroDevonian cover. 
but also the Chain Lakes Massif (Boucot, 1969, p. 50; Osberg et al., 1985). Thus, the age of obduction of the Jim Pond Formation cannot be younger than late Early Silurian. Boone and Boudette (1989) argue for a Late Cambrian-Early Ordovician age for obduction, associated with the amalgamation of their Boundary Mountains terrane (which includes the Chain Lakes Massif) with a terrane to the southeast.

In the field, the volcanics of the Jim Pond Formation are steeply dipping to slightly overturned and consistently face southward; a photograph of particularly well-developed pillow basalts that outcrop along Route 27 is shown in Fig. 3. Boudette (1982) interpreted the ophiolitic units to have been virtually in place (i.e., almost as they are seen today) by the end of the obduction event and argued that the effect of Acadian deformation was only broad warping and tightening of pre-existing folds.

In an attempt to unravel the tectonic history of central western Maine, paleomagnetic investigation of volcanics of the Jim Pond Formation was undertaken in order to determine its Cambrian paleogeographic position with respect to cratonic North America. Two Paleozoic remagnetization events, however, completely obscure the primary direction. Our results are, nevertheless, important for Appalachian geology. Firstly, the timing of these remagnetization events coincides with the timing of major orogenic events, which suggests that remagnetization and orogenic activity are spatially as well as temporally related (van der Pluijm et al., 1989). Secondly, Acadian remagnetization is not widely observed, but our results indicate that it may be more common in Lower to Middle Paleozoic rocks of the northern Appalachians than currently recognized.

\section{Sampling and laboratory procedures}

Previous experience in paleomagnetic investigation of Lower Paleozoic units of the northern Appalachians prompted us to concentrate our sampling in pillow volcanics of the Jim Pond Formation. Over one hundred samples were collected from ten sites; seven sites were taken from pillow basalts and three from felsic or andesitic units. Five sites were drilled in the field using a portable gas-powered drill. Oriented hand samples were taken from the remaining sites and drilled in the lab; standard paleomagnetic cores $(2.2 \times 2.5$ $\mathrm{cm})$ were used. The locations of our sampling sites are shown by the filled circles in Fig. 1.

Alternating field (AF) demagnetization was carried out with a Schonstedt GSD-1 AF demag-

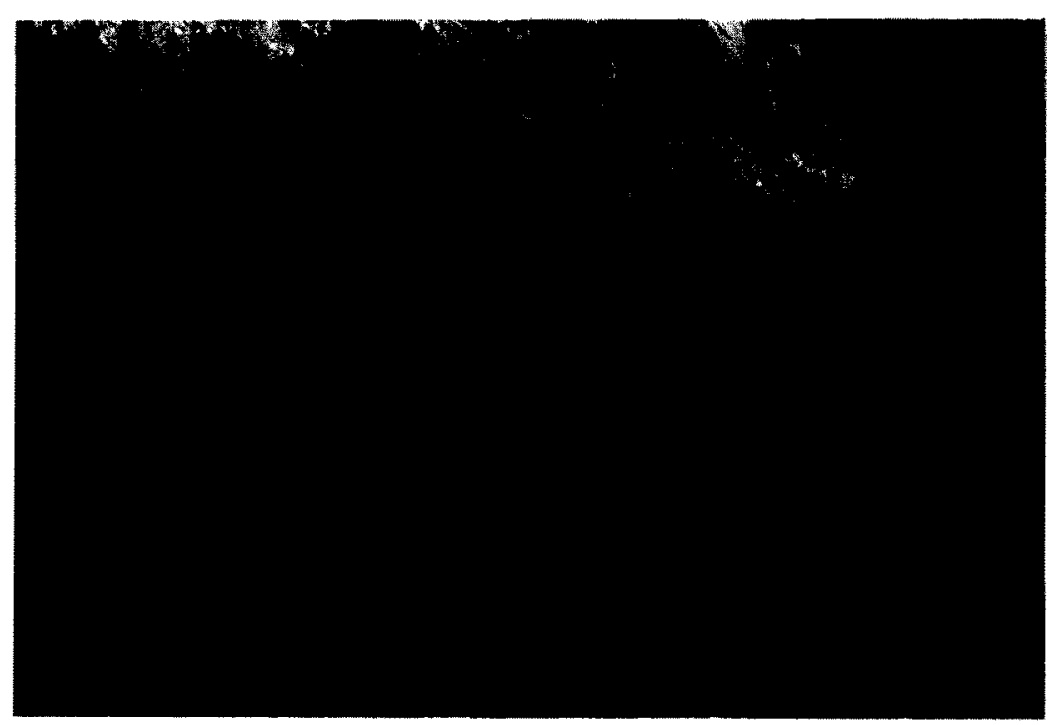

Fig. 3. Well-developed pillow basalts outcropping along Route 27. South is to the right; field notebook in the lower left comer for scale: these pillows are just above paleomagnetic sampling site jp1. Bedding orientation is steeply dipping (overturned) to the north. 
netizer and a Schonstedt TSD-1 furnace was used for thermal cleaning of the samples. Remanent magnetizations were measured on a Schonstedt SSM-1A spinner magnetometer for those samples with intensities greater than $1.62 \times 10^{-3} \mathrm{~mA} / \mathrm{m}$. A Scientific Technologies (ScT) two-axis cryogenic magnetometer was used to measure the remanence in weaker samples and in later demagnetization steps. Demagnetization data were plotted on orthogonal vector diagrams (Zijderveld, 1967) and equal-area stereographic projections. Best-fit lines and/or planes were then obtained using Principle Component Analysis (PCA) after Kirschvink (1980). Mean component directions and cones of confidence were calculated utilizing both the bestfit planes and lines after Halls (1976), and Bailey and Halls (1984).

\section{Results}

Stepwise demagnetization of samples collected from the Jim Pond Formation revealed three distinct components of magnetization. The components can be distinguished on the basis of unblocking temperature range and magnetic direction. After using both $\mathrm{AF}$ and thermal cleaning techniques on a pilot study of sixteen samples, it was clear that AF cleaning did not adequately isolate the components. The results discussed here are confined to thermal demagnetizations of four sites collected from pillow basalts. Among the six remaining sites, two were truly erratic (jp8 and jp10) and in one (jp2), although the demagnetizations defined a north-northeasterly and steeply upward direction (in situ), the results do not agree with those from other sites, suggesting that the entire block is not in place (e.g. slumped). Finally, three sites exhibit Component $I$ as the intersection of great circle trends, but Components II and III cannot be unambiguously demonstrated; these sites will not be included in the discussion below.

The first of three components of magnetization is shown in Fig. 4. It is typically removed by $350^{\circ} \mathrm{C}$ and clusters about a northerly and steeply downward direction in situ (Fig. 4a). The expected orientation of the present day field (PDF) at the site location closely coincides with the mean of Component I (Fig. 4b). Because Component I is subparallel to the PDF, we interpret it to be a recent partial overprint. In the orthogonal vector diagrams of Fig. 5, both Components I and II can be recognized. After removal of Component I by $350^{\circ} \mathrm{C}$, only Component II remains in these samples from site 9; the latter is typically removed over an intermediate temperature range (380$595^{\circ} \mathrm{C}$ ). In these samples, Component II has a well-defined, south-southeasterly and shallow direction that decays gradually and linearly to the origin. Samples that exhibit only Components I and II, but where neither component could be
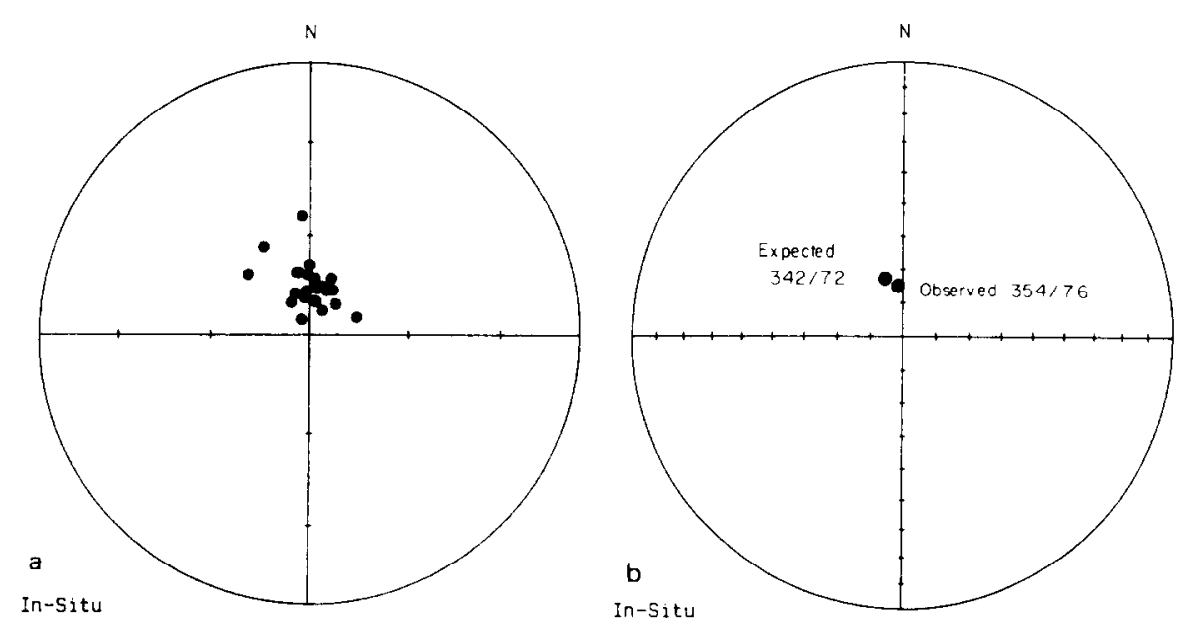

Fig. 4. Equal area projections showing, in (a), the sample distribution of Component I clustering about a northerly and steeply downward direction and (b) comparison of the mean of the cluster in (a) with the expected direction of the PDF for the site location $\left(45.3^{\circ} \mathrm{N}, 289.4^{\circ} \mathrm{W}\right)$. All points are plotted in the lower hemisphere, and are in geographic coordinates. 
completely isolated, are also observed. Component $\mathrm{II}$ is also shown in Figs. $6 \mathrm{a}$ and $6 \mathrm{~b}$, but with slightly different behavior. In Fig. $6 \mathrm{a}$, the curvilinear demagnetization path and the accompanying great-circle trend (from $520^{\circ}$ to $620^{\circ} \mathrm{C}$; Fig. $6 \mathrm{~d})$ indicate the simultaneous removal of two components of magnetization. In Fig. 6b, Component II is removed over a similar temperature range, but in this case it trends smoothly away from the origin until $615-625^{\circ} \mathrm{C}$, when the remaining remanence unblocks suddenly and unpredictably towards the origin; the accompanying great-circle trend from $500^{\circ}$ to $615^{\circ} \mathrm{C}$ (Fig. 6d) indicates the incomplete isolation of Component II and the simultaneous removal of yet another component.

Component III is observed as linear trajectories, but is also inferred to be present when high temperature great-circle trends are observed. The demagnetizations of two samples that exhibit only Components I and III as linear trajectories are shown in Fig. $7 \mathrm{a}$ and $7 \mathrm{~b}$. Component $\mathrm{I}$ persists to higher temperatures in this arrangement, but is typically removed by $600^{\circ} \mathrm{C}$. Component III is north-northeasterly and shallow upward; it usually unblocks over a higher temperature range $\left(580-695^{\circ} \mathrm{C}\right)$ and may appear to bypass the origin

jp9.9

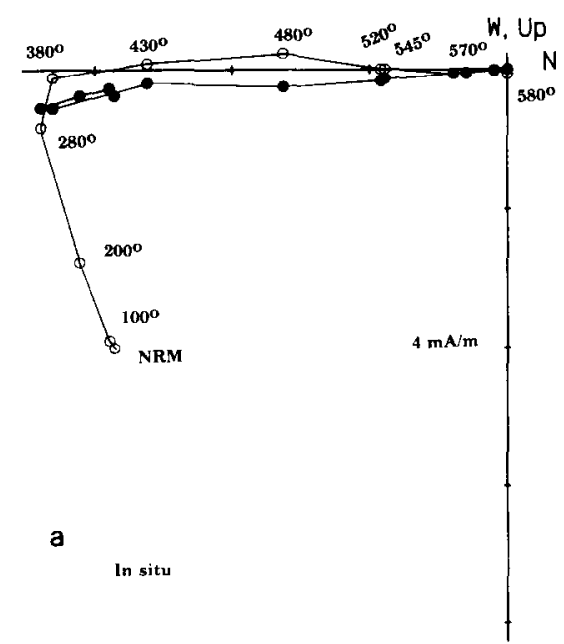

although the last measurement could be showing a spurious remanence acquired during treatment (Fig. 7a). Occasionally, as shown in the demagnetization of sample jp1.7 (Fig. 6c), Component III is incompletely isolated and is removed simultaneously with Component I. The simultaneous removal of Components I and III generates a great circle trend, that, when combined with those obtained from the demagnetizations of samples jp6.4 and jp1.8, yields a convergence at a north-northeasterly and shallow direction (Fig. 6d). The high unblocking temperatures observed upon demagnetization (e.g., in sample jp1.7) and the convergence at a direction similar to those observed as linear trajectories imply that it is the same direction. These two observations of Component III can be combined in a calculation of the formation mean direction (Bailey and Halls, 1984).

The difference in unblocking temperature ranges discussed above suggests that magnetite is a significant carrier of Component II, and that hematite is a significant carrier of Component III. In summary, on the basis of this difference and magnetic directions, the pillow basalts of the Jim Pond Formation are interpreted to exhibit three distinct components of magnetization: (I) PDF or

\section{jpg.10a}

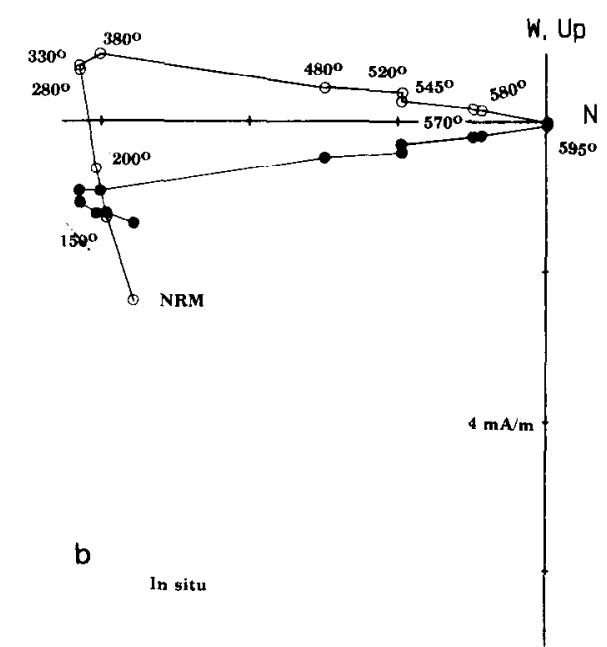

Fig. 5. Orthogonal vector diagrams (Zijderveld, 1967) showing the thermal demagnetization of two samples from site jp9. Temperatures are in degrees Celsius, closed (open) circles are projected onto the horizontal (vertical) plane, intensity of magnetization is plotted on the vertical axis (in $\mathrm{mA} / \mathrm{m}$ ). Components I (northerly and steep) and II (south-southeasterly and shallow) can be seen. 
jp6. 4

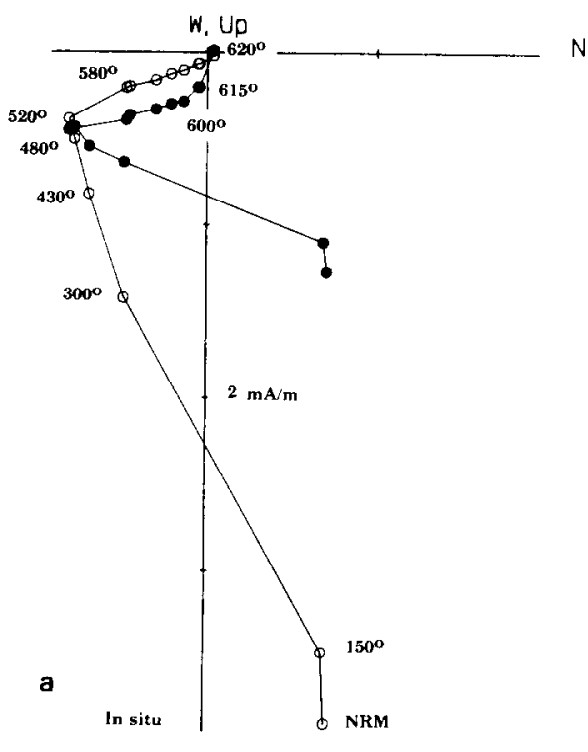

jp 1.7

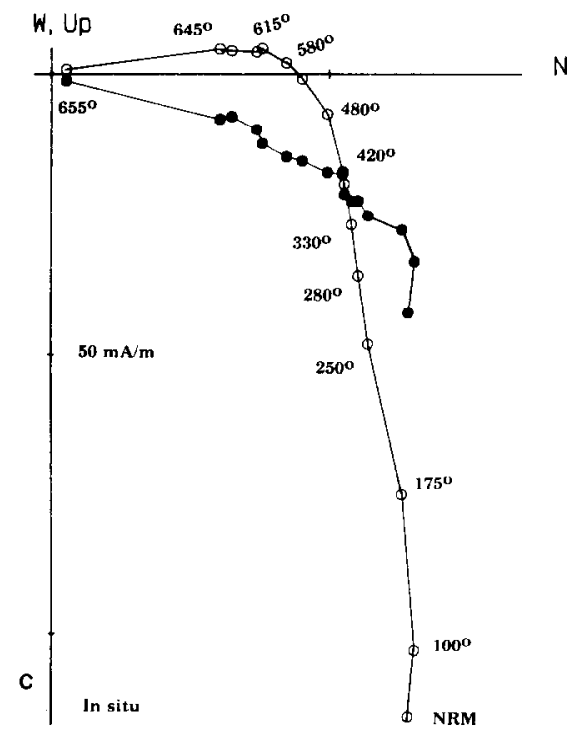

jp 1.8

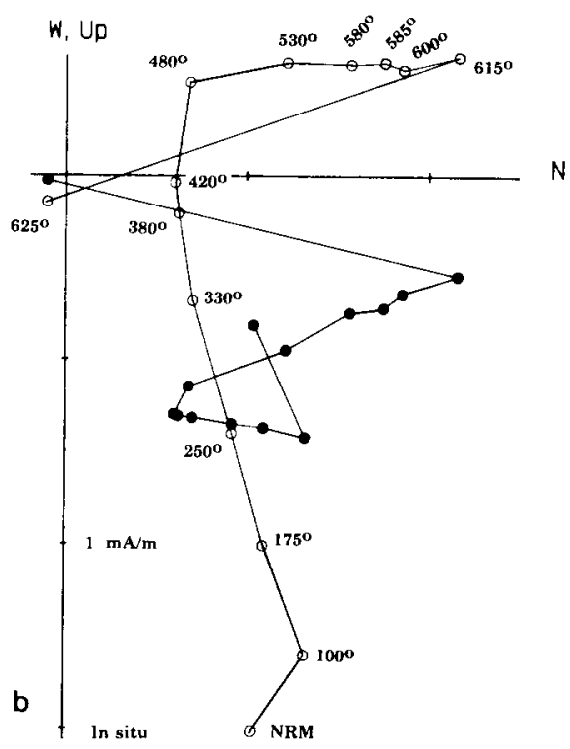

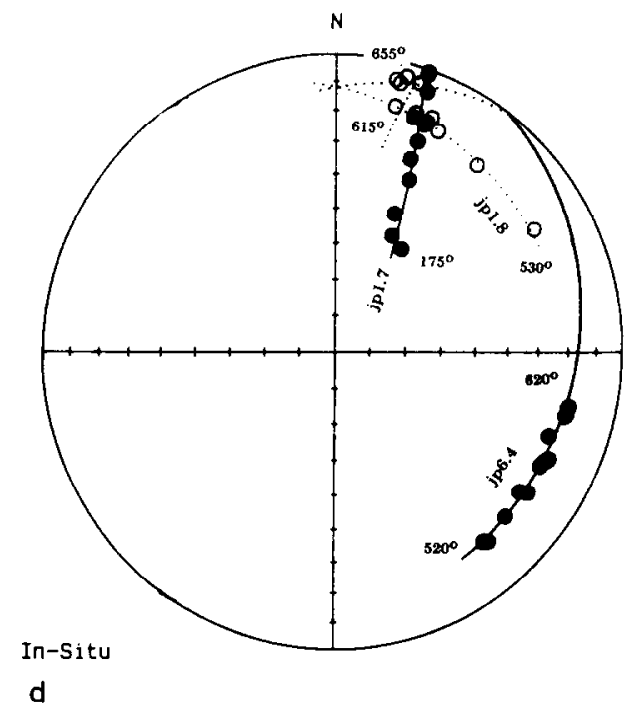

Fig. 6. (a) Orthogonal vector diagrams (in-situ) showing thermal demagnetization of sample jp6.4 (see caption for Fig. 5 for details). After removal of Component I by $480^{\circ} \mathrm{C}$, Components II and III are simultaneously removed by $620^{\circ} \mathrm{C}$. The best-fit great circle For the $520-620^{\circ} \mathrm{C}$ range is plotted in Fig. 6(d). (b) Thermal demagnetization of sample jp1.8 (see caption for Fig. 5 for details). Components I, II, and III are observed in this sample. Component I is unblocked by $480^{\circ} \mathrm{C}$. Component II from $480^{\circ}$ to $615^{\circ} \mathrm{C}$, and Component III is believed present because of the high temperature great circle trend observed. The best-fit great circle is plotted in Fig. 6d for the $530-615^{\circ} \mathrm{C}$ range. (c) Thermal demagnetization of sample jp1.7 (see caption for Fig. 5 for details). Because of the incomplete separation of Components I and III, a best-fit great circle was calculated for the $175-655^{\circ} \mathrm{C}$ range; it is plotted in Fig. 6(d). (d) Equal-area projection showing the great circle trends for samples jp1.8, jp6.4, and jp1.7; the actual data points and their associated temperature ranges are also plotted. Open circles are plotted in the upper hemisphere and closed circles are plotted in the lower hemisphere. 

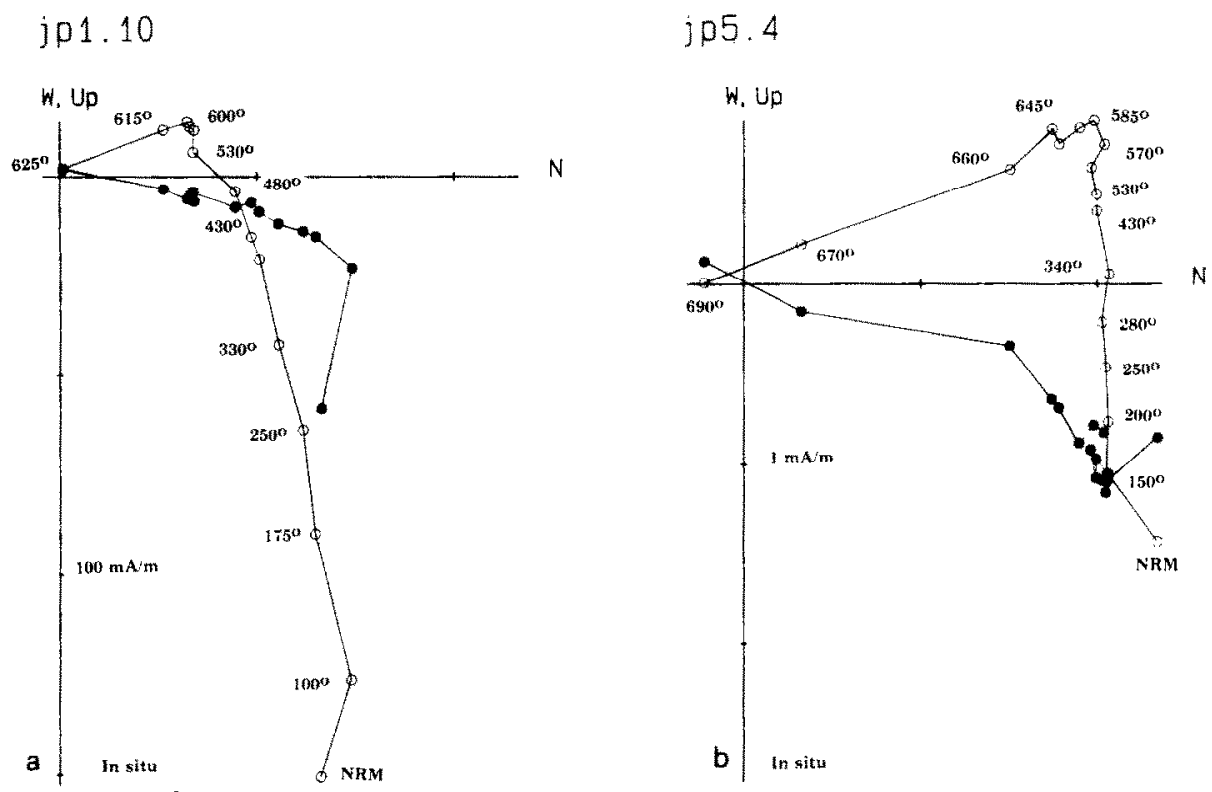

Fig. 7. Orthogonal vector diagrams (in-situ) showing the thermal demagnetization of samples from two different sites (a) jp1 and (b) jp5 (see Fig. 5 for explanation). Components I (northerly and steeply downward) and III (north-northeasterly and shallow upward) are seen.

\section{TABLE 1}

Sample directions used to calculate Component II

\begin{tabular}{|c|c|c|c|c|c|c|c|}
\hline \multirow[t]{2}{*}{$\begin{array}{l}\text { Sample } \\
\text { ID }\end{array}$} & \multirow[t]{2}{*}{$\begin{array}{l}\text { Str./Dip } \\
\left({ }^{\circ}\right)\end{array}$} & \multicolumn{3}{|c|}{$\begin{array}{l}\text { Poles to best-fit } \\
\text { great circles }\end{array}$} & \multicolumn{3}{|l|}{ Best-fit line } \\
\hline & & & $\begin{array}{l}\text { in-situ } \\
\left({ }^{\circ}\right)\end{array}$ & $\begin{array}{l}\text { tilt-corr. } \\
\left({ }^{\circ}\right)\end{array}$ & $\begin{array}{l}\text { in-situ } \\
\left({ }^{\circ}\right)\end{array}$ & & $\begin{array}{l}\text { tilt-corr. } \\
\left({ }^{\circ}\right)\end{array}$ \\
\hline $\mathrm{jp} 1.1$ & \multirow[t]{3}{*}{$065 / 85 \mathrm{~N}$} & & & & $163 /-12$ & & $310 /-71$ \\
\hline jp1.2 & & & & & $156 /-11$ & & $331 /-74$ \\
\hline jp1.8 & & & & & $157 / 13$ & & $006 /-85$ \\
\hline jp6.1a & \multirow[t]{6}{*}{$068 / 80 \mathrm{~S}$} & & & & $172 / 15$ & & $187 /-62$ \\
\hline jp6.2 & & \multicolumn{2}{|r|}{$063 /-1$} & $245 /-4$ & & & \\
\hline jp6b.2 & & & & & $162 / 17$ & & $177 /-68$ \\
\hline jp6b.3b & & \multicolumn{2}{|r|}{$065 /-72$} & $040 /-1$ & & & \\
\hline jp6.4 & & \multicolumn{2}{|r|}{$072 /-19$} & $049 /-7$ & & & \\
\hline jp6.8a & & & & & $154 /-1$ & & $134 /-80$ \\
\hline jp9.3a & \multirow[t]{5}{*}{$079 / 77 \mathrm{~S}$} & \multirow{3}{*}{\multicolumn{2}{|c|}{$\begin{array}{l}088 /-1 \\
273 /-2 \\
080 /-15\end{array}$}} & $079 /-10$ & & & \\
\hline jp9.5 & & & & $264 / 14$ & & & \\
\hline jp9.6 & & & & $064 /-4$ & & & \\
\hline jp9.9 & & & & & $177 /-2$ & & $205 /-76$ \\
\hline \multirow[t]{3}{*}{ jp9.10 } & & & & & $169 /-9$ & & $169 /-86$ \\
\hline & \multicolumn{4}{|c|}{ Mean direction } & \multicolumn{3}{|l|}{ Corresponding pole } \\
\hline & $\begin{array}{l}D / I \\
\left({ }^{\circ}\right)\end{array}$ & $n$ & $k$ & $\begin{array}{l}a_{95} \\
\left({ }^{\circ}\right)\end{array}$ & lat., long. & $\begin{array}{l}\mathrm{d} p \\
\left({ }^{\circ}\right)\end{array}$ & $\begin{array}{l}\mathrm{d} m \\
\left({ }^{\circ}\right)\end{array}$ \\
\hline In situ & $165 / 00$ & 14 & 31.4 & 8.6 & $43^{\circ} \mathrm{N}, 130^{\circ} \mathrm{E}$ & 4.3 & 8.6 \\
\hline Tilt-corr. & $203 /-84$ & 14 & 27 & 9.2 & $56^{\circ} \mathrm{N}, 300^{\circ} \mathrm{E}$ & 17.6 & 18 \\
\hline
\end{tabular}

Note: $k$ is the estimation of the precision parameter, $a_{95}$ is the cone of confidence about the mean; $\mathrm{d} p, \mathrm{~d} m$ are the axes of the ellipsoid of confidence; site location: $45.3^{\circ} \mathrm{N}, 289.4^{\circ} \mathrm{W}$. 
northerly and steeply downward, (II) south-southeasterly and shallow (in situ) and (III) a northnortheasterly and shallow upward (in situ).

\section{Discussion}

Paleomagnetic investigation of volcanics of the Jim Pond Formation has revealed some of the complexities that deformation and metamorphism can introduce into such older rocks. Because some sites failed to reveal useful information, means were calculated by combining data from a number of sites (McElhinny, 1973). The distribution of the poles to best-fit great circles (squares) and lines (circles) used in the calculation of the mean of Component II are listed in Table 1 and plotted on an equal-area projection, along with the in-situ mean $\left(D / I=165^{\circ} / 0^{\circ} ; n=14, k=31.4, a_{95}=\right.$ $8.6^{\circ}$ ) shown as a filled square in Fig. 8a. Table 2 lists the samples used in the calculation of the mean of Component III and Fig. 8b shows the distribution of the linear trajectories (open circles) and the poles to best-fit great circles (squares). The triangle and circled $\times$ are the means obtained from the linear trajectories and the intersection of great circles, respectively. The best-fit great circle is also plotted (solid in the lower hemisphere, dotted in the upper). The mean of Component III that was calculated by combining the great circle trends and direct observations (lines) is $D / I=$ $10^{\circ} /-24^{\circ}\left(n=35, k=2.15, a_{95}=7.3^{\circ}\right)$ and is shown in Fig. 8b as the square with the $X$ in it with its cone of confidence (Bailey and Halls, 1984). It is this mean that was used to calculate the paleopole (for Component III) discussed in the next paragraph.

The paleomagnetic pole corresponding to Component II $\left(43^{\circ} \mathrm{N}, 130^{\circ} \mathrm{E} ; \mathrm{d} p, \mathrm{~d} m=4.3^{\circ}, 8.6^{\circ}\right)$, shown by the filled circle, falls near the Late Carboniferous segment of the Apparent Polar Wander Path (Fig. 9; Van der Voo, 1990). A Late Paleozoic remagnetization event is widespread in the Appalachian region of North America (e.g., McCabe and Elmore, 1990), and we interpret Component II to be the result of this event.

The paleomagnetic poles corresponding to the in-situ $\left(32^{\circ} \mathrm{N}, 98^{\circ} \mathrm{E} ; \mathrm{d} p, \mathrm{~d} m=4.2^{\circ}, 7.8^{\circ}\right)$ and tilt-corrected $\left(61^{\circ} \mathrm{N}, 73^{\circ} \mathrm{E} ; \mathrm{d} p, \mathrm{~d} m=4.9^{\circ}, 10.2^{\circ}\right)$
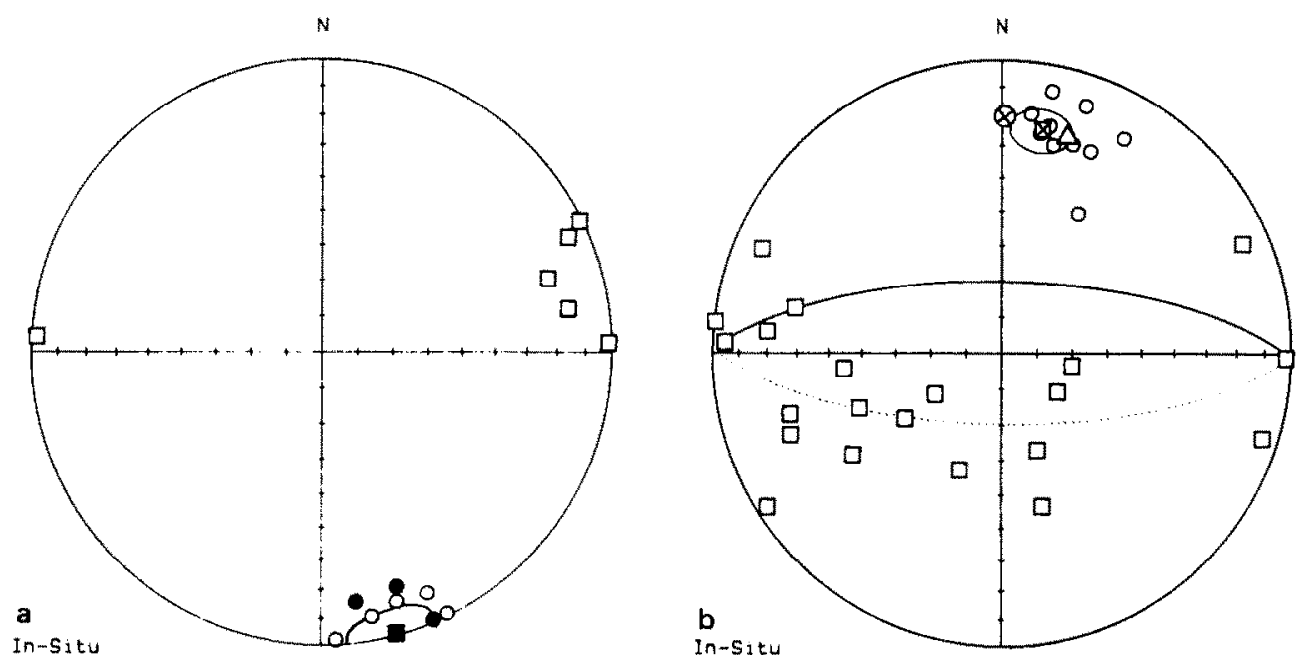

Fig. 8. (a) Equal-area projection (as in Fig. 6d) showing the sample distribution of those samples used to calculate the mean of Component II $\left(D / I=165^{\circ} / 0^{\circ} ; n=8, k=31.4, a_{95}=8.6^{\circ}\right)$. All symbols are plotted in-situ, the mean is indicated by the filled square, poles to best-fit great circles are plotted in the upper hemisphere as the open squares. (b) Equal-area projection showing the sample distribution used in the calculation of the mean of Component III. Squares are poles to best-fit great circles, open circles are directions obtained from best-fit lines. $\Delta=$ mean for directions obtained from linear trajectories only; $\otimes=$ mean obtained from the intersection of great circles only. The great circle that best-fit the data is plotted as dotted (solid) in the upper (lower) hemisphere. The mean calculated by combining great circles and stable endpoints is $D / I=10^{\circ} /-24^{\circ}\left(n=35, k=21.5, a_{95}=7.3^{\circ}\right.$ and is plotted as a square with and in the center of its cone of confidence. Open symbols (and all means) are plotted in the upper hemisphere; all symbols are plotted in-situ. 
TABLE 2

Sample directions used to calculate Component III

\begin{tabular}{|c|c|c|c|c|c|}
\hline \multirow[t]{2}{*}{$\begin{array}{l}\text { Sample } \\
\text { ID }\end{array}$} & \multirow[t]{2}{*}{$\begin{array}{l}\text { Str./Dip } \\
\left({ }^{\circ}\right)\end{array}$} & \multicolumn{2}{|c|}{$\begin{array}{l}\text { Poles to best-fit } \\
\text { great circles }\end{array}$} & \multicolumn{2}{|c|}{ Best-fit Line } \\
\hline & & $\begin{array}{l}\text { in-situ } \\
\left({ }^{\circ}\right)\end{array}$ & $\begin{array}{l}\text { tilt-corr. } \\
\left({ }^{\circ}\right)\end{array}$ & $\begin{array}{l}\text { in-situ } \\
\left({ }^{\circ}\right)\end{array}$ & $\begin{array}{l}\text { tilt-corr. } \\
\left({ }^{\circ}\right)\end{array}$ \\
\hline jp1.1 & $065 / 85 \mathrm{~N}$ & $265 /-45$ & $111 /-17$ & & \\
\hline $\mathrm{jp} 1.2$ & & $249 /-23$ & $088 /-6$ & & \\
\hline jpl.5 & & & & $030 /-17$ & $048 / 35$ \\
\hline jp1.6 & & $293 /-11$ & $076 /-48$ & & \\
\hline jp1.7 & & $108 /-6$ & $051 /-41$ & & \\
\hline jp1.8 & & $238 /-68$ & $133 /-2$ & & \\
\hline jp1.9 & & $276 /-1$ & $063 /-31$ & & \\
\hline jp1.10 & & & & $012 /-22$ & $036 / 50$ \\
\hline jp5.1 & $048 / 85 \mathrm{~S}$ & $272 /-5$ & $239 / 43$ & & \\
\hline jp5.2 & & & & $011 /-10$ & $033 / 35$ \\
\hline jp5.3 & & & & $024 /-26$ & $019 / 20$ \\
\hline jp5.4 & & & & $017 /-24$ & $019 / 26$ \\
\hline $\mathrm{jp} 5.5 \mathrm{a}$ & & & & $019 /-26$ & $017 / 24$ \\
\hline jp5.7 & & & & $019 /-12$ & $032 / 37$ \\
\hline $\mathrm{jp} 5.8$ & & & & $007 /-19$ & $021 / 37$ \\
\hline jp5.9a & & & & $029 /-45$ & $001 / 10$ \\
\hline jp5.10 & & & & $014 /-28$ & $014 / 27$ \\
\hline jp5.11 & & & & $010 /-31$ & $009 / 29$ \\
\hline jp6.1a & $068 / 80 \mathrm{~S}$ & $160 /-61$ & $336 /-38$ & & \\
\hline jp6b.3b & & $237 /-4$ & $250 /-10$ & & \\
\hline jp6.4 & & $125 /-70$ & $349 /-26$ & & \\
\hline jp6.6 & & $236 /-57$ & $124 / 14$ & & \\
\hline jp6.7a & & $066 /-10$ & $057 / 0$ & & \\
\hline jp6.7b & & $200 /-55$ & $311 /-33$ & & \\
\hline jp6.8b & & $101 /-70$ & $354 /-20$ & & \\
\hline jp6.10 & & $236 /-38$ & $285 /-15$ & & \\
\hline jp9.1 & $079 / 77 \mathrm{~S}$ & $254 /-25$ & $283 /-10$ & & \\
\hline jp9.4 & & $275 /-20$ & $282 / 10$ & & \\
\hline jp9.3 & & $091 /-2$ & $080 /-12$ & & \\
\hline jp9.5 & & $282 /-28$ & $292 / 13$ & & \\
\hline jp9.6 & & $249 /-46$ & $124 / 16$ & & \\
\hline
\end{tabular}

\begin{tabular}{|c|c|c|c|c|c|c|c|}
\hline & \multicolumn{4}{|c|}{ Mean direction } & \multicolumn{3}{|c|}{ Corresponding pole } \\
\hline & $\begin{array}{l}D / I \\
\left({ }^{\circ}\right)\end{array}$ & $n$ & $k$ & $\begin{array}{l}a_{95} \\
\left({ }^{\circ}\right)\end{array}$ & lat., long. & $\begin{array}{l}\mathrm{d} p \\
\left({ }^{\circ}\right)\end{array}$ & $\begin{array}{l}\mathrm{d} m \\
\left({ }^{\circ}\right)\end{array}$ \\
\hline In situ & $010 /-24$ & 31 & 21.5 & 7,3 & $32^{\circ} \mathrm{N}, 98^{\circ} \mathrm{E}$ & 4.7 & 7.8 \\
\hline Tilt-corr. & $018 / 37$ & 31 & 15,8 & 8.7 & $61^{\circ} \mathrm{N}, 73^{\circ} \mathrm{E}$ & $4.9^{\circ}$ & 10.2 \\
\hline
\end{tabular}

Note: $k$ is the estimation of the precision parameter, $a_{95}$ is the radius of the cone of confidence; $\mathrm{d} p, \mathrm{~d} m$ are axes of the ellipsoid of confidence; site location: $45.3^{\circ} \mathrm{N}, 289.4^{\circ} \mathrm{W}$.

means of Component III are also shown in Fig. 9 as the filled and open triangles, respectively. The in-situ direction yields a pole that is located near the Lower to Middle Devonian segment of the
North American APWP, while the pole corresponding to the tilt-corrected direction is located along the lower Jurassic segment of the APWP. The near constancy of structural attitude negates 


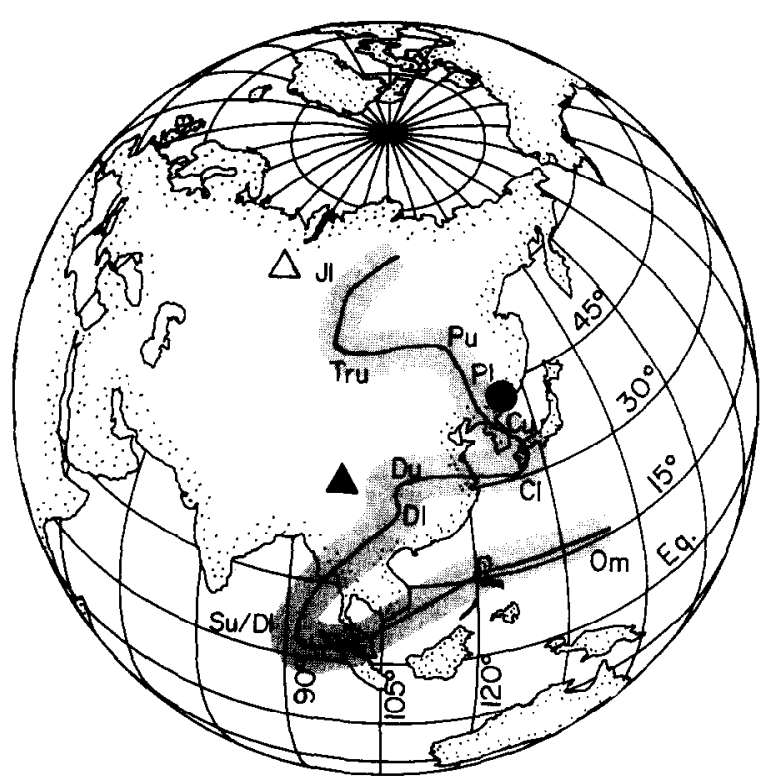

Fig. 9. Orthographic projection of present-day configuration of the continents centered on $35^{\circ} \mathrm{N}, 105^{\circ} \mathrm{E}$. Superimposed is the Apparent Polar Wander Path of Van der Voo (1990) for the Middle Ordovician $(\mathrm{Om})$ through the Lower Jurassic $(\mathrm{Jl})$. Paleopoles calculated from in-situ mean directions are closed symbóls, the open symbol is a pole calculated from the tilt-corrected mean direction; triangles represent the poles for Component $I I$ and the circle represents Component II.

the possibility of applying a significant fold test to date the magnetizations as pre- or post-folding, but for both Components I and II, the precision parameter, $k$, decreases and the $a_{95}$ increases when the structural correction is applied (see Tables 1 and 2), suggesting a post-folding magnetization. The folding of the Jim Pond Formation is pre-Carboniferous; thus the magnetization cannot be simultaneously pre-folding and Jurassic in age as would be implied by the tilt-corrected pole. This, plus the similarity of the in-situ pole of Component III with Devonian poles from North America, suggests the existence of a Devonian remagnetization event.

The correlation of the ages of the two remagnetization events and the timing of Paleozoic orogenic activity in the northern Appalachians is particularly noteworthy. Component II is a result of a widespread late Paleozoic remagnetization event which temporally coincides with the Alleghenian orogeny. Component III is a less commonly reported manifestation of a Devonian remagnetiza- tion event which coincides with widespread Acadian orogenic activity.

\section{Mechanisms of remagnetization}

Recent reinvestigation of many older paleomagnetic studies have underscored the importance of recognizing remagnetizations (Van der Voo, 1989). Many of the observations of Late Paleozoic remagnetizations are in sedimentary rocks of the central and southern Appalachians where deformation associated with the Alleghenian orogeny was most penetrative (Hatcher, 1987), but documented cases extend to relatively undeformed (Craddock and van der Pluijm, 1989) sedimentary rocks of the interior of the continent (Suk et al., 1989). While the method by which rocks are remagnetized is not completely understood, diagenesis or fluid-induced growth of significant magnetite or hematite appears to be the most often cited method for remagnetizing sedimentary rocks (McCabe et al., 1983, 1984; Miller and Kent, 1988; McCabe and Elmore, 1990).

Remagnetization of volcanic rocks is even less well understood. The Jim Pond Formation exhibits mineral assemblages typical of lowest greenschist facies metamorphism (Boudette, 1982). Heizler and Lux (1988), who dated plutons in the area and modeled the cooling history of the Chain of Ponds Pluton (see also De Yoreo et al., 1989), estimated the ambient temperature to be $350^{\circ} \mathrm{C}$ in the late Middle Devonian. With the average cooling rate of $2^{\circ}$ to $3^{\circ} \mathrm{C} / \mathrm{Ma}$ obtained by Heizler and Lux (1988), the temperature by the late Carboniferous would be insufficient $\left(\mathrm{ca} .200^{\circ} \mathrm{C}\right.$ ) to cause thermal resetting of magnetites with laboratory blocking temperatures of $500-600^{\circ} \mathrm{C}$ (Pullaiah et al., 1975; Middleton and Schmidt, 1982). The nearest evidence of a Carboniferous heat source is southeast of the study area near the Sebago Batholith (U-Pb age, $325 \pm 3 \mathrm{Ma}$; Aleinikoff et al., 1985) where Lux and Guidotti (1985) reported evidence for Late Paleozoic metamorphism. The age for the metamorphism coincides with the age estimate for the paleomagnetic pole (Late Carboniferous) and, thus, the remagnetization event. The distance, mineral assemblage and the argon loss profiles of nearby plutons (Heizler and Lux, 1988), however, appear to pro- 
hibit the direct association of the Late Paleozoic remagnetization with the intrusion of the Sebago batholith. Nevertheless, we believe that a thermal resetting of magnetite is the most likely mechanism for Alleghenian remagnetization of the Jim Pond Formation in the Late Paleozoic.

Acadian orogenic activity is most extensive in the northern Appalachians, (Williams, 1984) and the intrusion of plutonic rocks dated as Middle Devonian (e.g., Big Island Pond Pluton, Spider Lake Granite and the Chain of Ponds Pluton; Heizler and Lux, 1988; De Yoreo et al., 1989) provides a favorable environment for the acquisition of a partial thermo-remanent magnetization (pTRM). However, Component III is carried by hematite, whose high unblocking temperatures indicate that the Acadian remagnetization must be a chemical remanent magnetization (CRM). The different carriers of the magnetization for components II and III (magnetite and hematite, respectively) and the estimates of post-Acadian temperatures discussed above explain the survival of Component III through the Late Paleozoic remagnetization event.

\section{Implications for other Appalachian paleomagnetic studies}

Comparison of the in-situ mean of Component III (Acadian remagnetization) with previous paleomagnetic results from volcanic rocks in the northern Appalachians has provided some new insights. Spariosu and Kent 1983) investigated the paleomagnetism of the Lower Devonian Traveler felsite in order to determine its paleolatitude and define the limits of the "Acadia terrane". After $\mathrm{AF}$ and thermal demagnetization, two components were observed: (1) a southerly and intermediate component that is completely removed by $600^{\circ} \mathrm{C}$ and (2) a north-northeasterly and shallow upward component that is not completely removed until $650^{\circ} \mathrm{C}$. In the analysis of their demagnetizations, Spariosu and Kent (1983) concluded that these directions were antipodal and, thus, they combined them to calculate formation means. Their results, however, closely resemble ours. Unfortunately, Spariosu and Kent (1983) only thermally demagnetized a series of pilot samples; more detailed thermal treatment could have provided better evidence for the existence of two separate components, comparable to our Components II and III. We contend that the Lower Devonian Traveler felsite contains what is perhaps a primary magnetization, but more likely an Acadian remagnetization (probably in the Black Cat member) as well as a Late Paleozoic remagnetization (probably in the basal Pogy member). In either case, if the north-northeasterly direction is primary or an Acadian remagnetization, the existence of the Acadia terrane of Spariosu and Kent (1983) is doubtful.

Kent and Opdyke (1980) investigated the Siluro-Devonian Hersey and Eastport formations and concluded that formation means, obtained by combining results from different lithologies, approximated the Siluro-Devonian geomagnetic field. Roy (1982) asserted that Kent and Opdyke's results actually represent a Devono-Carboniferous remagnetization that was acquired in a subsequent orogeny (i.e., the Acadian or Alleghenian), based on a recalculation of formation means. The paleopole corresponding to the combination of results from the Eastport Formation and the red beds (only) of the Hersey Formation is $33^{\circ} \mathrm{N}$, $105^{\circ} \mathrm{E}\left(\mathrm{d} p, \mathrm{~d} m=3^{\circ}, 5^{\circ}\right.$ ), Roy's (1982) recalculated pole is located near the Devonian segment of the APWP and compares favorably with the pole calculated from the in-situ direction of Component III obtained in this study $\left(32^{\circ} \mathrm{N}, 98^{\circ} \mathrm{E}\right)$. Roy's pole, however, was calculated from only the reversed polarity directions observed by Kent and Opdyke (1980); therefore, if the Eastport Formation was remagnetized during the Acadian orogeny, it was not contemporaneous with the remagnetization of the Jim Pond Formation or the (re?) magnetization of the Traveler felsite and occurred when the geomagnetic field was reversed. This difference in timing may explain the slight longitudinal difference $\left(7^{\circ}\right)$ between our pole and Roy's pole (see also Stearns and Van der Voo, 1988).

\section{Conclusion}

Paleomagnetic investigation of mafic volcanics of the Jim Pond Formation indicates the presence of two Paleozoic remagnetization events: 
(1) a Late Paleozoic thermal resetting of magnetite, at least part of which is probably induced by long-term heating from surrounding plutons;

(2) an Early to Middle Devonian chemical remagnetization carried by hematite.

Without a conclusive fold test to date the time of acquisition of either Component II or III, the age of neither can be unequivocally established. However, comparison of the inferred ages of the corresponding paleopoles with the timing of Paleozoic orogenic activity indicates that remagnetization of Appalachian units is associated with the regional deformation (van der Pluijm et al., 1989). We predict that close examination of other paleomagnetic results from New England will give additional evidence for, in particular, Acadian remagnetizations. The frequent reversals of the Devonian geomagnetic field and a rough similarity with primarily reversed late Paleozoic directions, however, may hinder its recognition.

\section{Acknowledgments}

We thank Gary Boone, Eugene Boudette, Dick Goldsmith, Rex Johnson, and Elton Lombard for discussions and guidance during fieldtrips. This work was supported by a Rackham Minority Fellowship, a U.S.G.S. graduate internship, and a scholarship from the American Geological Institute's Minority Participation Program (ADL), and the National Science Foundation, grants EAR 86-12469 and 89-05811.

\section{References}

Aleinikoff, J.N. and Moench, R.H., 1985. Metavolcanic stratigraphy in northern New England-U-Pb zircon geochronology. Geol. Soc. Am., Abstr. Progr., 17: 1.

Aleinikoff, J.N., Moench, R.H and Lyons, J.B., 1985. Carboniferous U-Pb age of the Sebago batholith, southwestern Maine. Geol. Soc. Am. Bull., 96: 990-996.

Ando, C.J., Cook, F.A., Oliver, J.E., Brown, L.D. and Kaufman, S., 1983. Crustal geometry of the Appalachian orogen from seismic reflection studies. In: R.D. Hatcher, Jr., H. Williams and I. Zietz (Editors), Contributions to the Tectonics and Geophysics of Mountain Chains. Geol. Soc. Am., Mem., 158: 83-101.

Ayuso, A.A., 1986. Lead-isotopic evidence for distinct sources of granite and for distinct basements in the northern Appalachians, Maine. Geology, 14: 322-325.
Bailey, R.C. and Halls, H.C., 1984. Estimate of confidence in paleomagnetic directions derived from mixed remagnetization circle and direct observational data. J. Geophys. Res., 54: 174-182.

Boone, G.M. and Boudette, E.L., 1989. Accretion of the Boundary Mountains terrane within the northern Appalachian orthotectonic zone. In: J.W. Horton Jr. and N. Rast (Editors), Melanges and Olistostromes of the U.S. Appalachians. Geol. Soc. Am. Spec. Pap., 228: 17-42.

Boucot, A.J., 1969. Geology of the Moose River and Roach River Synclinoria northwestern Maine. Maine Geol. Surv. Bull., 21: 117 pp.

Boudette, E.L., 1978. Stratigraphy and structure of the Kennebago Lake Quadrangle, central western Maine. Ph.D. thesis, Dartmouth College, Hanover, N.H., 342 pp.

Boudette, E.L., 1982. Ophiolite assemblage of early Paleozoic age in central western Maine. In: St. Julien and J. Beland (Editors), Major Structural Zones and Faults of the Northern Appalachians. Geol. Assoc. Can. Spec. Pap., 24: 209 230.

Boudette, E.L and Boone, G.M., 1976. Pre-Silurian stratigraphic succession in central western Maine. In: L.R. Page (Editor), Contributions to the stratigraphy of New England. Geol. Soc. Am., Mem., 148: 79-96.

Coish, R.A. and Rogers, N.W., 1987. Geochemistry of the Boil Mountain ophiolitic complex, northwest Maine, and tectonic implications. Contrib. Mineral, Petrol., 97: 51-65.

Craddock, J. and van der Pluijm, B.A., 1989. Late Paleozoic deformation of the cratonic cover of eastern North America. Geology, 17: 416-419.

De Yoreo, J.J., Lux, D.R., Guidotti, C.V., Decker, E. R. and Osberg, P.H., 1989. The Acadian thermal history of western Maine. J. Metamorph. Geol., 7: 169-190.

Eisenberg, R.A., 1982. Chronostratigraphy and lithogeochemistry of Lower Paleozoic rocks from the Boundary Mountains, west-central Maine. Ph.D. thesis, Univ. of California, Berkeley, Calif., $180 \mathrm{pp}$.

Halls, N.C., 1976. A least-squares method to find a remanence direction from converging remagnetization circles. Geophys. J. R. Astron. Soc., 45: 297-304.

Hatcher, R.D., Jr., 1987. Tectonics of the southern and central Appalachian Internides. Annu. Rev. Earth Planet. Sci., 15: $337-362$.

Heizler, M.T. and Lux, D.R., 1988. The age and cooling history of the Chain of Ponds and Big Island Pond plutons and the Spider Lake Granite, west-central Maine and Quebec. Am. J. Sci., 288: 925-952.

Kirschvink, J.L., 1980. The least-squares line and plane and the analysis of palaeomagnetic data. Geophys. J. R. Astron. Soc., 62: 699-718.

Kent, D.V. and Opdyke, N.D., 1980. Paleomagnetism of Siluro-Devonian rocks from eastern Maine. Can. J. Earth Sci., 17: 1653-1665.

Lombard, A.D., 1990. Acadian and Alleghanian remagnetization of the Jim Pond Formation, control western Maine, northern Appalachians. M. Sc. thesis, University of Michigan, Ann Arbor, Mich., 50 pp. 
Lux, D.R. and Guidotti, C.V., 1985. Evidence for extensive Hercynian metamorphism in western Maine. Geology, 13: 696-700.

McCabe, C. and Elmore, R.D., 1990. The occurrence and origin of Late Paleozoic remagnetization in the sedimentary rocks of North America. Rev. Geophys., 27: 471-494.

McCabe, C., Van der Voo, R., Peacor, D.R., Scotese, C.R. and Freeman, R., 1983. Diagenetic magnetite carries ancient yet secondary remanence in some Paleozoic sedimentary carbonates. Geology, 11: 221-223.

McCabe, C., Van der Voo, R. and Ballard, M.M., 1984. Late Paleozoic remagnetization of the Trenton Limestone. Geophys. Res. Lett., 11: 979-982.

McElhinny, M.W., 1973. Palaeomagnetism and Plate Tectonics. Cambridge University Press, Cambridge, 358 pp.

Middleton, M.F. and Schmidt, 1982. Paleothermometry of the Sydney Basin. J. Geophys. Res., 87: 5351-5359.

Miller, J.D. and Kent, D.V., 1988. Regional trends in the timing of Alleghenian remagnetization in the Appalachians. Geology, 16: 588-591.

Naylor, R.B., Boone, G.M., Boudette, E.L., Ashenden, D.O. and Robinson, P., 1973. Pre-Ordovician rocks in the Bronson Hill and Boundary Mountains anticlinoria, New England, U.S.A. Eos, Trans. Am. Geophys. Union, 54: 495.

Osberg, P.H., 1978. Synthesis of the geology of the northeastern Appalachians. U.S.A. In: Caledonian-Appalachian Orogeny of the North Atlantic Region. Geol. Surv. Can., Pap., 78-13: 137-147.

Osberg, P.H., Hussey, A.M. and Boone, G.M., 1985. Bedrock Geologic Map of Maine. Maine Geological Survey, scale $1: 500,000$.

Pullaiah, G., Irving, E., Buchan, K.L., and Dunlop. D.J., 1975. Magnetization changes caused by burial and uplift. Earth Planet. Sci. Lett., 28: 133-143.

Roy, J.L., 1982. Paleomagnetism of Siluro-Devonian rocks from eastern Maine, Discussion. Can. J. Earth Sci., 19: 225-232.

Spariosu, D.J. and Kent, D.V., 1983. Paleomagnetism of the lower Devonian Traveler felsite and the Acadian orogeny in the New England Appalachians. Geol. Soc. Am. Bull., 94: 1319-1328.

Spencer, C., Green, A., Morel-a-l'Huissier, P., Milkereit, B., Luetgert, J., Stewart, D., Unger, J. and Phillips, J., 1989. The extension of Grenville basement beneath the northern Appalachians: results from the Quebec-Maine seismic reflection and refraction surveys. Tectonics, 8: 677-696.

Stearns, C. and Van der Voo, R., 1988. Dual polarity magnetizations from the Upper Devonian McAras Brook Formation, Nova Scotia, and their implications for the North American apparent polar wander path. Tectonophysics, 156: 179-191.

Suk, D., Van der Voo, R. and Peacor, D.R., 1989. Late Paleozoic remagnetization of the Trenton Limestone in the Michigan Basin. Eos, Trans. Am. Geophys. Union, 70: 310.

van der Pluijm, B.A., Van der Voo, R. and McWhinnie, S.T., 1989. Timing relationship between deformation and remagnetization. Eos, Trans. Am. Geophys. Union, 70: 311.

Van der Voo, R., 1989. Paleomagnetism of North America: the craton, its margins, and the Appalachian Belt. In: L.C. Pakiser and W.D. Mooney (Editors), Geophysical Framework of the Continental United States. Geol. Soc. Am., Mem., 171:447-470.

Van der Voo, R., 1990. Phanerozoic paleomagnetic poles from Europe and North America and comparisons with continental reconstructions. Rev. Geophys., 28:167-206

Williams, H., 1984. Miogeoclines and suspect terrranes of the Caledonian-Appalachian orogen: Tectonic patterns in the North Atlantic region. Can. J. Earth Sci., 21: 887-901.

Zen, E-an, 1983. Exotic terranes in the New England Appalachians: Limits, candidates, and ages. A speculative essay. In: R.D. Hatcher, Jr., H. Williams and I. Zietz (Editors), Contributions to the Tectonics and Geophysics of Mountain Chains. Geol. Soc. Am., Mem., 158: 55-81.

Zijderveld, J.D.A., 1967. AC demagnetization of rocks: analysis of results. In: D.W. Collinson, K.M. Creer and S.K. Runcorn (Editors), Methods in Paleomagnetism. Elsevier, Amsterdam, pp. 254-286. 